\title{
KARAKTERISTIK SENSORI BEBERAPA PRODUK IKAN ASAP KHAS DAERAH DI INDONESIA DENGAN MENGGUNAKAN METODE QUANTITATIVE DESCRIPTIVE ANALYSIS
}

\section{Sensory Characteristics of Several Indonesian Indigineous Smoked Fish Products using Quantitative Descriptive Analysis Method}

\author{
Rusky Intan Pratama ${ }^{1 \star}$, Heru Sumaryanto², Joko Santoso ${ }^{2}$, dan Winarti Zahirudin ${ }^{2}$ \\ ${ }^{1}$ Mahasiswa Sekolah Pascasarjana Program Studi THP-Fakultas Perikanan IImu Kelautan, Institut Perikanan Bogor \\ 2 Staf Pengajar Sekolah Pascasarjana Program Studi THP-Fakultas Perikanan IImu Kelautan, Institut Perikanan Bogor \\ * Korespondensi Penulis: rusky_pratama@yahoo.com
}

\begin{abstract}
ABSTRAK
Komoditas ikan asap merupakan salah satu produk pangan tradisional (exotic indigenous food) yang sangat dikenal oleh masyarakat Indonesia. Penelitian ini dilakukan sebagai bagian dari upaya pemetaan produk olahan ikan khas daerah di Indonesia sebagai upaya protektif terhadap kekayaan bangsa Indonesia. Tahapan penelitian terdiri dari 2 tahap. Tahap pertama yaitu pengambilan sampel 4 jenis ikan asap khas daerah di Indonesia (ikan fufu, ikan salai, ikan pe, ikan kayu) dari masing-masing pengolah ikan asap (Bitung, Padang, Rembang, Kendari) serta dilanjutkan dengan tahap kedua yaitu pengujian organoleptik yang dilakukan di laboratorium khusus flavor. Metode Quantitative Descriptive Analysis (QDA) yang dilanjutkan dengan Principal Component Analysis (PCA) digunakan untuk menjelaskan karakteristik flavor sampel berdasarkan atribut aroma dan rasa yang diuji oleh 10 panelis terlatih. Karakteristik sensori yang diamati ialah atribut aroma yang terdiri dari smoky, fishy, burnt, fatty, woody, dan sweet serta atribut rasa yang terdiri dari manis, asam, asin, pahit dan gurih. Hasil analisis QDA menunjukkan bahwa ikan kayu memiliki intensitas aroma fishy $(53,97)$, woody $(37,77)$ dan rasa gurih $(47,62)$ yang lebih tinggi dari ikan asap jenis lainnya. Ikan pe memiliki intensitas aroma burnt $(36,02)$ dan smoky $(62,32)$ yang lebih tinggi. Ikan fufu memiliki intensitas rasa pahit $(28,58)$, asin $(34,17)$ dan asam $(39,82)$ yang lebih tinggi serta ikan salai memiliki intensitas aroma fatty $(27,57)$, sweet $(28,75)$ dan rasa manis $(33,10)$ yang lebih tinggi dibandingkan ikan asap jenis lainnya. Hasil PCA (PC1 47\%; PC2 37\%) menunjukkan sampel ikan asap dikelompokkan ke dalam empat kuadran berbeda bersama dengan atribut-atribut sensoris yang menjadi karakteristiknya.
\end{abstract}

KATA KUNCI: ikan asap, produk khas daerah, uji QDA

\section{ABSTRACT}

Smoked fish commodities are very well known for Indonesian people and considered as one of Indonesian exotic indigineous food. This study is a part of Indonesia's traditional processed fish product's mapping as an effort to protect one of many Indonesia's valuable assets. This study was carried out in two stages. The first one was collecting four local Indonesian smoked fish samples (ikan fufu, ikan salai, ikan pe, ikan kayu) from each of its manufacturer and in second stage, samples were assessed using sensory evaluation in specific flavor laboratory. Quantitative Descriptive Analysis with Principal Component Analysis was used to evaluate flavor characteristics based on taste and aroma attributes that were assessed by 10 trained panelists. Sensory characteristics observed were aroma attributes which consists of smoky, fishy, burnt, fatty woody and sweet and also taste attributes which consists of sweet, sour, salty, bitter and umami. The QDA results showed that ikan kayu had higher intensity of fishy (53.97), woody (37.77) aroma and umami taste (47.62) compared with the other three. Ikan pe had higher burnt (36.02) and smoky aroma intensit (62.32). Ikan fufu had higher intensity of bitter $(28,58)$, salty (34.17) and sour (39.82) taste and ikan salai had higher intensity of fatty (27.57), sweet (28.75) aroma and sweet taste (33.10). PCA result (PC1 47\%; PC2 37\%) showed that smoked fish samples were categorize into four different quadrants along with sensory attributes which become its characteristics.

KEYWORDS: smoked-fish, exotic-indigenous-food, QDA 


\section{PENDAHULUAN}

Pengasapan memberikan nilai lebih jika dibandingkan dengan produk perikanan yang diolah dengan penggaraman atau pengeringan. Pada saat ini pengasapan ikan dilakukan dengan alasan utama untuk memberikan penampakan dan flavor yang khas (Martinez et al., 2007), yang dapat dideteksi, diidentifikasi atau dipersepsi dengan indera manusia. Flavor merupakan komponen yang kompleks, dapat berbentuk volatil atau non-volatil yang dapat berperan sebagai aroma atau sebagai rasa. Pada ikan asap, flavor yang ditimbulkan dipengaruhi oleh kandungan senyawa volatil seperti fenolik dan karbonil (Toth \& Potthast, 1984) serta kandungan senyawa non volatil seperti asam amino bebas dan garam anorganik.

Karakteristik sensori ikan asap yang ada di Indonesia akan bergantung pada beberapa faktor seperti perbedaan jenis bahan baku, jenis bahan bakar, metode pengasapan, jenis alat, dan kondisi pengasapan yang digunakan. Ada juga produk ikan asap yang sebenarnya sama tetapi dikenal dengan nama berbeda di daerah lain. Masing-masing daerah produsen biasanya memiliki ciri khas dalam pengolahan ikan asap ini, sehingga karakteristik sensori produk akhirnya pun akan berbeda. Kesimpulan yang seragam tentang suatu karakteristik sensori ikan asap yang ideal sebagai hasil generalisasi masing-masing daerah sulit untuk diperoleh karena produk ikan asap yang dihasilkan bergantung dari berbagai faktor proses pengolahan dan selera konsumen masing-masing daerah. Beberapa contoh produk ikan asap khas Indonesia di antaranya ialah ikan salai dari Sumatera Barat; ikan fufu dari Sulawesi Utara; ikan pe dari Jawa Tengah dan ikan kayu dari Sulawesi Tenggara. Adanya perbedaan proses pengolahan dan faktor-faktor yang telah disebutkan di atas akan mempengaruhi karakteristik flavor ikan asap yang dihasilkan.

Di Indonesia, penelitian ikan asap umumnya berkisar pada proses metode dan kondisi pengasapan serta daya simpan ikan asap, sebagaimana dilaporkan oleh beberapa peneliti antara lain Rieuwpassa (1991) mengenai daya awet ikan tongkol asap, Zakaria (1996) tentang mutu ikan bilih asap, Giyatmi (2000) mengenai kapang pada ikan kayu dan Aqliyanto (2005) tentang mutu ikan lele asap. Sementara itu penelitian mengenai karakteristik flavor ikan asap khas dari wilayah Indonesia hingga saat ini belum banyak ditemukan.

Penelitian lain terkait dengan ikan asap telah dilaporkan oleh para peneliti Jepang yang melakukan identifikasi flavor dari ikan asap sejak tahun 1960-an. Hal ini diketahui dari ditemukannya jurnal mengenai analisis komponen flavor katsuobushi yang dilakukan oleh Kokichi Nishibori pada tahun 1965 (Nishibori, 1965). Penelitian negara lain terutama mengkaji mengenai pengaruh proses pengasapan terhadap kualitas dan beberapa karakteristik ikan asap (Birkeland et al., 2004; Oyelese 2006; Martinez et al., 2007) serta komponen volatil ikan asap (Sakakibara et al., 1990ª Sakakibara et al., 1990; Guillen \& Errecalde 2002; Guillen et al., 2006; Varlett et al., 2007; Jonsdottir et al., 2008).

Persepsi dari indera manusia terhadap suatu sifat produk dapat diukur dengan metode pengujian organoleptik. Walaupun senyawa volatil yang berpengaruh terhadap flavor dapat dideteksi menggunakan instrumen analisis tertentu tetapi sensasi flavor yang diterima oleh manusia hanya bisa diukur secara organoleptik. Pengaruh dari berbagai flavor yang berbeda terhadap pemilihan konsumen hanya bisa dinilai oleh uji sensori subyektif (Noble, 2006). Evaluasi mengenai flavor memiliki sifat dasar yang sangat subjektif sehingga ada yang menilai bahwa analisis kuantitatif secara objektif tidak tepat untuk dilakukan. Untuk keperluan riset maka panelis terlatih yang harus berperan dalam menilai atau mengukur flavor utama dan intensitasnya.

Uji organoleptik deskriptif merupakan uji yang paling canggih dari sekian metodologi organoleptik yang ada, khususnya bagi ahli-ahli organoleptik (dibandingkan dengan metode diskriminasi dan penerimaan) (Stone \& Sidel, 2004). Hasil dari analisis deskriptif memberikan deskripsi lengkap dari suatu jajaran produk sehingga dapat menjadi dasar untuk memetakan persamaan dan perbedaan produk dan menentukan atribut sensoris yang penting bagi penerimaan produk (Meilgaard et al., 1999). Berdasarkan hal itu maka pada penelitian ini dilakukan metode pengujian organoleptik deskriptif yaitu metode Quantitative Descriptive Analysis (QDA).

Hasil penelitian ikan asap bersifat spesifik bagi masing-masing produk ikan asap, oleh karena itu penelitian mengenai karakteristik sensori ikan asap perlu dilakukan. Penelitian ini bertujuan untuk mengidentifikasi karakteristik sensori (khususnya flavor) dari empat jenis ikan asap tradisional khas Indonesia (ikan fufu, salai, pe, dan kayu) berdasarkan metode pengujian deskriptif sebagai upaya pemetaan produk olahan ikan khas daerah di Indonesia.

\section{BAHAN DAN METODE}

\section{Penelitian Lapangan}

Penelitian dilaksanakan mulai dari bulan Oktober 2010 sampai dengan Januari 2011. Pengambilan sampel ikan asap dilakukan di Kota Rembang, Jawa 
Tengah; Padang, Sumatera Barat; Bitung, Sulawesi Utara dan Kendari, Sulawesi Tenggara. Analisis kimia dilakukan di Laboratorium Konservasi Satwa Langka dan Harapan, Laboratorium Terpadu Institut Pertanian Bogor dan Laboratorium Flavor Balai Besar Penelitian Tanaman Padi (BBPTP), Sukamandi, Subang, Jawa Barat.

Pada tahap penelitian lapangan dilakukan pengambilan sampel sebanyak $4 \mathrm{~kg}$. Ikan fufu diambil dari Kelompok Langsa 2 (Bitung), ikan pe dari Kelompok Sukoharjo (Rembang), ikan salai dari CV DA Pabata (Padang) dan ikan kayu (arabushi) dari CV Ome (Kendari). Sampel-sampel tersebut dikemas menggunakan alumunium foil, plastik cling wrap dan disimpan dalam kemasan tertier (kotak plastik atau kardus) lalu di bawa ke Bogor. Pada saat pengambilan sampel juga dilakukan pengambilan data primer dengan cara mengamati proses secara langsung dan melakukan wawancara dengan narasumber ahli mengenai proses pembuatan ikan asap tersebut.

\section{Penelitian Laboratorium}

Pada tahap analisis laboratorium, sampel yang telah selesai dipreparasi (dibagi dan ditimbang) kemudian diuji organoleptik deskriptif menggunakan metode Quantitative Descriptive Analysis (modifikasi dari Meilgaard et al., 1999). Pada penelitian ini metode QDA dibagi menjadi beberapa tahap yaitu perekrutan dan pelatihan panelis, pengembangan bahasa atribut deskripsi, uji konsistensi panelis dan tahap pengujian QDA.

\section{Perekrutan dan Pelatihan Panelis}

Pada tahap ini dilakukan pengisian kuesioner prescreening, uji segitiga aroma dan rasa dasar, uji deskripsi flavor dan uji ranking terhadap ikan asap yang dilakukan oleh 10 panelis terlatih yang berada di lingkungan Laboratorium Flavor BBPTP, Sukamandi. Pengujian dilakukan dalam laboratorium khusus organoleptik yang terdiri dari 10 booth uji. Uji segitiga dilakukan untuk mengumpulkan data-data dasar panelis yang mengikuti uji dan mengetahui kemampuan panelis dalam membedakan aroma dan rasa dasar. Pengujian ini dilakukan sebanyak 4 sesi. Panelis diminta mengisi lembar kuesioner uji segitiga yang ada pada layar komputer. Standar yang digunakan ialah standar atribut aroma yaitu fishy (squalane), smoky (guaiacol), burnt (furfuril mercaptan), fatty (Butter 09002) dan standar untuk atribut rasa manis (sukrosa), pahit (kafein), asin (garam), asam (asam sitrat), gurih (MSG).

Uji deskripsi flavor menggunakan 4 standar aroma yaitu fishy, smoky, burnt, fatty, dan uji ranking flavor bagi panelis terlatih juga dilakukan pada tahap ini. Pengujian ini dilakukan sebanyak 4 sesi. Uji deteksi dapat menghasilkan sekelompok panelis yang dapat mendeteksi terjadinya perubahan kecil pada produk, namun belum cukup dalam memilih panelis untuk melakukan analisis deskriptif. Panelis juga harus mampu untuk membedakan dan menggambarkan dengan cukup baik beberapa atribut kunci sensoris dari sampel-sampel produk yang diuji dan juga harus dapat menunjukkan kemampuan untuk menggambarkan perbedaan intensitas dari atribut sensoris yang terdeteksi. Jumlah panelis terlatih yang akan berpartisipasi pada uji QDA ${ }^{\circledR}$ ini ialah sebanyak 10 orang.

\section{Pengembangan Bahasa Atribut Deskripsi}

Tahap ini dilakukan dalam 1 sesi dan dirancang untuk mempersiapkan panelis dengan latar belakang yang kuat sebagai dasar untuk melakukan uji dan memulai penilaian terhadap karakteristik yang berbeda dari berbagai jenis produk yang berbeda. Tahap kedua ini dimulai dengan pengenalan produk yang akan diuji dan melakukan diskusi secara kelompok yang dipimpin oleh panel leader yang meliputi pengembangan bahasa deskripsi produk dibandingkan dengan standar yang telah dikenal sebelumnya. Hasil diskusi yang dilakukan sepakat untuk menambahkan standar aroma woody dan sweet karena sebagian panelis mendeteksi adanya kedua atribut tersebut pada sampel-sampel yang disajikan. Kedua deskripsi aroma ini selanjutnya akan digunakan selama pengujian-pengujian pada tahap selanjutnya. Standar yang digunakan untuk kedua aroma ini ialah 1-octen-3-ol untuk woody dan hexyl acetate untuk sweet.

\section{Uji Konsistensi}

Tahap ketiga dilakukan untuk menentukan konsentrasi standar dan melatih kemampuan panelis dalam menetapkan skala standar aroma dan rasa yang digunakan. Penggunaan skala intensitas referensi selama pelatihan dimaksudkan untuk memberikan kekuatan pengertian dari atribut maupun intensitas produk. Uji konsistensi ini dilakukan dalam 6 sesi. Banyaknya sesi yang dilakukan akan bergantung pada kekonsistenan hasil penilaian panelis terhadap intensitas atribut flavor sampel. Pada tahap ini telah digunakan lembar penilaian berskala yang sama dengan pengujian QDA yaitu dengan skala garis sepanjang $15 \mathrm{~cm}$ untuk menentukan intensitas atribut. Hasil pengukuran dalam skala garis tersebut lalu dikonversi menjadi nilai 0-100. Data yang diperoleh kemudian diolah dan dimasukkan dalam persamaan Moskowitz (Setyaningsih et al., 2010): 


$$
\log \mathrm{SI}=\log \mathrm{K}+\mathrm{n}(\log \mathrm{PI})
$$

Keterangan/Note:

$\begin{array}{ll}\text { SI (Sensory Intensity) } & \text { Perkiraan intensitas yang } \\ & \text { terdeteksi } \\ \text { PI (Physical Intensity) }= & \text { Konsentrasi flavor } \\ \text { Log K } & \text { Konstanta } \\ \mathrm{n} & =\end{array}$

\section{Pengujian QDA ${ }^{\circledR}$}

Pengujian QDA ${ }^{\circledR}$ dilakukan dalam 4 sesi pengujian oleh masing-masing panelis terlatih. Sampel ikan asap disajikan pada panelis beserta standar-standar aroma dan rasa yang digunakan. Panelis kemudian mengisi lembar penilaian skala garis pada komputer yang telah diberi intensitas berdasarkan konsentrasi standar yang digunakan pada pengujian (untuk aroma 30, 50, 70 , dan untuk rasa 25,50 , dan 75 ). Intensitas standar ini digunakan untuk memudahkan panelis dalam mengkuantifikasi atribut sensoris yang terdeteksi. Intensitas standar yang ditampilkan beserta konsentrasi standar yang digunakan diperoleh berdasarkan hasil perhitungan dari data uji konsistensi dan hasilnya tersaji pada Tabel 1. Intensitas yang semakin tinggi memiliki arti bahwa atribut sensoris pada sampel semakin dapat terdeteksi. Panelis harus menentukan apakah atribut-atribut yang terdeteksi tersebut lebih rendah, tinggi atau sama dengan intensitas standar yang telah ditentukan. Panelis mengevaluasi atribut-atribut yang terdapat pada sampel berdasarkan intensitas standar-standar tersebut. Data hasil rata-rata yang diperoleh dari pengujian organoleptik metode QDA diplotkan ke dalam grafik spider web (Microsoft Office Excel 2007). Selanjutnya dilakukan analisis statistika multivariat Principal Component Analysis (PCA) menggunakan software The Unscrambler ${ }^{\circledR}$ 9.6 (Camo Software AS).

PCA merupakan metode analisis statistika multivariat yang digunakan untuk mentransformasikan variabel-variabel asli menjadi variabel-variabel baru yang mempunyai dimensi lebih kecil dan saling bebas antara variabel satu dengan variabel lainnya. Variabelvariabel baru tersebut merupakan kombinasi linear dari variabel aslinya dan dinamakan komponen utama (Principle Component/PC). Analisis ini mampu menjelaskan $75-90 \%$ dari total keragaman dalam data yang mempunyai $25-30$ variabel hanya dengan $2-3$ PC. Jumlah PC yang akan digunakan harus menerangkan minimal $70 \%$ total keragaman data. Jika kurang dari 70\%, maka akan diambil PC selanjutnya dan seterusnya hingga jumlah varians kumulatifnya lebih dari $70 \%$. Metode ini cenderung digunakan untuk pengelompokkan, mengetahui hubungan pengelompokan antara contoh dan variabel dan mendeteksi adanya outliers (Setyaningsih et al., 2010).

Hasil analisis PCA merupakan gabungan dari plot loading dan scores dalam bentuk grafik biplot. Loading menyatakan gambaran hubungan (korelasi) antara variabel-variabel (yang diamati) dalam setiap komponen utama dan scores menggambarkan sifatsifat subjek (sampel). Grafik biplot menggambarkan hubungan antara variabel dan sampel secara keseluruhan. Jarak antara titik variabel menunjukkan hubungan di antara variabel. Interpretasi untuk titiktitik sampel sama dengan interpretasi variabel. Hubungan antara dua titik sampel dapat dilihat dengan membandingkan jaraknya dengan titik-titik dari variabel. Titik-titik sampel yang berdekatan menunjukkan bahwa sampel-sampel tersebut sama, sedangkan titik-titik sampel yang berjauhan menunjukkan hal yang sebaliknya.

\section{HASIL DAN BAHASAN}

\section{Proses Pengasapan Ikan di Beberapa Daerah}

Hasil inventarisasi disusun berdasarkan wawancara dan pengamatan langsung terhadap proses pengasapan yang dilakukan. Tabel 2 menyajikan hasil inventarisasi proses dari keempat sampel ikan asap pada masing-masing daerah.

Pembuatan ikan fufu dilakukan dalam suatu ruang pengasapan khusus walaupun sangat sederhana. Proses pengasapan akan menghasilkan produk yang baik jika dilakukan pada lingkungan yang kering, oleh karena itu proses pengasapan sebaiknya dilakukan di dalam sebuah ruang pengasapan dibandingkan pada udara terbuka (Berkel, 2004). Prosedur pengasapan yang berbeda telah dikembangkan di beberapa daerah dan hasilnya akan dipengaruhi oleh sifat-sifat ikan yang digunakan, kondisi cuaca pada saat pengasapan dan tingkat teknologi secara umum. Istilah pengasapan panas memang tidak memberikan informasi yang terinci mengenai waktu dan kisaran suhu yang digunakan, umumnya suhu yang digunakan berkisar antara $50-80^{\circ} \mathrm{C}$ (Doe, 1998).

Pengeringan awal yang dilakukan pada pengasapan ikan salai berfungsi untuk mencegah penutupan lapisan luar ikan sebagai akibat dari pengerasan lapisan luar selama pengasapan. Ikan tidak akan mengering dengan sempurna selama pengasapan jika pengerasan terjadi karena kelembaban yang tertahan di dalam kulit ikan. Ikan yang telah melalui proses pengeringan sebelum pengasapan akan memiliki lapisan permukaan yang mengkilap (Berkel, 2004). Terdapat tiga tahap proses 
Tabel 1 Atribut, definisi, referensi standar dan intensitas pengujian QDA

Table 1. Attributes, definition, standard references and intensity for QDA

\begin{tabular}{|c|c|c|c|}
\hline $\begin{array}{l}\text { Istilah/ } \\
\text { Attributes }\end{array}$ & DefinisilDefinition ${ }^{*}$ & $\begin{array}{l}\text { Referensi Standarl } \\
\text { Standard Reference }\end{array}$ & $\begin{array}{l}\text { Inte nsitas/ } \\
\text { Intensity }\end{array}$ \\
\hline \multirow{3}{*}{$\begin{array}{l}\text { Hangus/ } \\
\text { Burnt }\end{array}$} & \multirow{3}{*}{$\begin{array}{l}\text { Aroma hangus terbakar/Aroma } \\
\text { associated with burnt or burned } \\
\text { out }\end{array}$} & furfuril mercaptan $0.54 \mathrm{ml} / 5 \mathrm{ml} \mathrm{PG}$ & 30 \\
\hline & & furfuril mercaptan $3.47 \mathrm{ml} / 5 \mathrm{ml} \mathrm{PG}$ & 50 \\
\hline & & furfuril mercaptan $11.84 \mathrm{ml} / 5 \mathrm{ml} \mathrm{PG}$ & 70 \\
\hline \multirow{3}{*}{$\begin{array}{l}\text { Asap/ } \\
\text { Smoky }\end{array}$} & \multirow{3}{*}{$\begin{array}{l}\text { Aroma dari asap kayu dari } \\
\text { perapian/Aroma associated with } \\
\text { smoke from bonfire }\end{array}$} & guaiacol $12.61 \mathrm{ml} / 5 \mathrm{ml} \mathrm{PG}$ & 30 \\
\hline & & guaiacol $36.71 \mathrm{ml} / 5 \mathrm{ml} \mathrm{PG}$ & 50 \\
\hline & & guaiacol $74.22 \mathrm{ml} / 5 \mathrm{ml} \mathrm{PG}$ & 70 \\
\hline \multirow{3}{*}{$\begin{array}{l}\text { Lemak/ } \\
\text { Fatty }\end{array}$} & \multirow{3}{*}{$\begin{array}{l}\text { Aroma makanan berlemak/ } \\
\text { Aroma associated with fatty food }\end{array}$} & Butter $0900240.05 \mathrm{ml} / 5 \mathrm{ml} \mathrm{PG}$ & 30 \\
\hline & & Butter $0900253.52 \mathrm{ml} / 5 \mathrm{ml} \mathrm{PG}$ & 50 \\
\hline & & Butter $0900264.79 \mathrm{ml} / 5 \mathrm{ml} \mathrm{PG}$ & 70 \\
\hline \multirow{3}{*}{$\begin{array}{l}\text { Amis/ } \\
\text { Fishy }\end{array}$} & \multirow{3}{*}{$\begin{array}{l}\text { Aroma yang berhubungan } \\
\text { dengan ikan yang sudah } \\
\text { disimpan/tidak segar/Aroma } \\
\text { associated with aged fish }\end{array}$} & Squalene $17.37 \% / 5 \mathrm{ml} \mathrm{PG}$ & 30 \\
\hline & & Squalene $57.61 \% / 5 \mathrm{ml} \mathrm{PG}$ & 50 \\
\hline & & Squalene $126.92 \% / 5 \mathrm{ml} \mathrm{PG}$ & 70 \\
\hline \multirow{3}{*}{$\begin{array}{l}\text { Manis/ } \\
\text { Sweet }\end{array}$} & \multirow{3}{*}{$\begin{array}{l}\text { Aroma manis pada makanan } \\
\text { masak/Sweet aroma in cooked } \\
\text { food }\end{array}$} & hexyl acetate $1.61 \mathrm{ml} / 5 \mathrm{ml} \mathrm{PG}$ & 30 \\
\hline & & hexyl acetate $9.38 \mathrm{ml} / 5 \mathrm{ml} \mathrm{PG}$ & 50 \\
\hline & & hexyl acetate $29.94 \mathrm{ml} / 5 \mathrm{ml} \mathrm{PG}$ & 70 \\
\hline \multirow{3}{*}{$\begin{array}{l}\text { Kayu/ } \\
\text { Woody }\end{array}$} & \multirow{3}{*}{$\begin{array}{l}\text { Aroma dari kayu segar dan } \\
\text { basah, atau jamur/Odour } \\
\text { characteristic for fresh, wet } \\
\text { wood }\end{array}$} & octen-1-3-ol $1.98 \mathrm{ml} / 5 \mathrm{ml} \mathrm{PG}$ & 30 \\
\hline & & octen-1-3-ol $6.04 \mathrm{ml} / 5 \mathrm{ml} \mathrm{PG}$ & 50 \\
\hline & & octen-1-3-ol $12.61 \mathrm{ml} / 5 \mathrm{ml} \mathrm{PG}$ & 70 \\
\hline \multirow{3}{*}{$\begin{array}{l}\text { Manis/ } \\
\text { Sweet }\end{array}$} & \multirow{3}{*}{$\begin{array}{l}\text { Rasa pada lidah yang } \\
\text { berhubungan dengan gula/The } \\
\text { taste on the tongue associated } \\
\text { with sugar }\end{array}$} & Larutan sukrosa/Sucrose solution $0.60 \%$ & 25 \\
\hline & & Larutan sukrosa/Sucrose solution $1.27 \%$ & 50 \\
\hline & & Larutan sukrosa/Sucrose solution $1.97 \%$ & 75 \\
\hline \multirow[t]{3}{*}{$\begin{array}{l}\text { Asam/ } \\
\text { Sour }\end{array}$} & \multirow{3}{*}{$\begin{array}{l}\text { Sensasi rasa yang umumnya } \\
\text { karena keberadaan asam-asam } \\
\text { organik/Taste sensation, } \\
\text { generally due to the presence of } \\
\text { organic acids }\end{array}$} & Larutan asam sitrat/Citric acid solution $0.021 \%$ & 25 \\
\hline & & Larutan asam sitrat/Citric acid solution $0.041 \%$ & 50 \\
\hline & & Larutan asam sitrat/Citric acid solution $0.059 \%$ & 75 \\
\hline \multirow{3}{*}{$\begin{array}{l}\text { Asin/ } \\
\text { Salty }\end{array}$} & \multirow{3}{*}{$\begin{array}{l}\text { Rasa di lidah yang berhubungan } \\
\text { dengan garam atau natrium/The } \\
\text { taste on the tongue associated } \\
\text { with salt or sodium }\end{array}$} & Larutan $\mathrm{NaCl} / \mathrm{NaCl}$ solution $0.222 \%$ & 25 \\
\hline & & Larutan $\mathrm{NaCl} / \mathrm{NaCl}$ solution $0.532 \%$ & 50 \\
\hline & & Larutan $\mathrm{NaCl} / \mathrm{NaCl}$ solution $0.888 \%$ & 75 \\
\hline \multirow{3}{*}{$\begin{array}{l}\text { Pahit/ } \\
\text { Bitter }\end{array}$} & \multirow{3}{*}{$\begin{array}{l}\text { Rasa pahit biasanya karena } \\
\text { kafein dan quinin/Taste that } \\
\text { common to caffeine and quinine }\end{array}$} & Larutan kafein/Caffeine solution $0.017 \%$ & 25 \\
\hline & & Larutan kafein/Caffeine solution $0.028 \%$ & 50 \\
\hline & & Larutan kafein/Caffeine solution $0.038 \%$ & 75 \\
\hline \multirow[t]{3}{*}{$\begin{array}{l}\text { Gurih/ } \\
\text { Umami }\end{array}$} & $\begin{array}{l}\text { Rasa yang dihasilkan dari } \\
\text { senyawa seperti MSG dalam }\end{array}$ & Larutan MSG/MSG solution $0.023 \%$ & 25 \\
\hline & larutan/Taste produced by & Larutan MSG/MSG solution $0.057 \%$ & 50 \\
\hline & $\begin{array}{l}\text { substances such as } \\
\text { monosodium glutamate (MSG) }\end{array}$ & Larutan MSG/MSG solution $0.096 \%$ & 75 \\
\hline
\end{tabular}

Keterangan/Note: * Definisi diperoleh dari Codex Allimentarius (1999), Kostyra \& Pikielna (2006); Varlet et al. (2007)/Definition from Codex Allimentarius (1999), Kostyra \& Pikielna (2006); Varlet et al. (2007) 
Tabel 2. Proses pengasapan empat jenis ikan asap di Indonesia

Table 2. Smoking process of four smoked fish in Indonesia

\begin{tabular}{|c|c|c|c|c|c|}
\hline \multirow{2}{*}{\multicolumn{2}{|c|}{$\begin{array}{l}\text { Parameterl } \\
\text { Parameters }\end{array}$}} & \multicolumn{4}{|c|}{ Jenis Ikan Asap/Kinds of Smoked Fish } \\
\hline & & Ikan Fufu & Ikan Salai & Ikan Kayu & Ikan Pe \\
\hline a. & Bahan bakul & Cakalang/ & Lele dumbo/ & Cakalang/ & Pari/Rayfish \\
\hline & Rawmaterial & Skipjack tuna & Catfish & Skipjack tuna & \\
\hline b. & $\begin{array}{l}\text { Bahan bakarl } \\
\text { Smoke sources }\end{array}$ & $\begin{array}{l}\text { Sabut kelapal } \\
\text { Coconut } \\
\text { husks }\end{array}$ & $\begin{array}{l}\text { Meranti, serbuk } \\
\text { gergaji dan sabut } \\
\text { kelapa/Meranti } \\
\text { woods, sawdust } \\
\text { and coconut } \\
\text { husks }\end{array}$ & $\begin{array}{l}\text { Kayu Mahoni, } \\
\text { eha, limbah } \\
\text { jati/Mahogany } \\
\text { and eha woods } \\
\text { and teakwood } \\
\text { waste }\end{array}$ & $\begin{array}{l}\text { Sabut dan tempurung } \\
\text { kelapa, limbah } \\
\text { jati/Coconut shells } \\
\text { and husks, teakwood } \\
\text { waste }\end{array}$ \\
\hline c. & $\begin{array}{l}\text { Alat pengasapan/ } \\
\text { Smoking equipment: }\end{array}$ & $\begin{array}{l}\text { Ruang } \\
\text { pengasapan/ } \\
\text { Smoking } \\
\text { chamber }\end{array}$ & $\begin{array}{l}\text { Oven asap/ } \\
\text { Smoking oven }\end{array}$ & $\begin{array}{l}\text { Ruang } \\
\text { pengasapan/ } \\
\text { Smoking } \\
\text { chamber }\end{array}$ & $\begin{array}{l}\text { Tungku asap } \\
\text { tradisional/Traditional } \\
\text { smoking kiln }\end{array}$ \\
\hline & $\begin{array}{l}\text { - Dimensi/ } \\
\text { Dimension }\left(\mathrm{m}^{3}\right)\end{array}$ & $6 \times 4 \times 4$ & $1 \times 0.9 \times 1$ & $4 \times 2 \times 4$ & $0.8 \times 0.6 \times 0.1$ \\
\hline & - Bahan/Material & $\begin{array}{l}\text { Seng, kayu, } \\
\text { rak bambul } \\
\text { Zinc plates, } \\
\text { woods, } \\
\text { bamboos } \\
\text { shelves }\end{array}$ & $\begin{array}{l}\text { Besi, } 5 \text { tray } \\
\text { stainless } \\
\text { steel/Iron, } 5 \\
\text { stainless steel } \\
\text { trays }\end{array}$ & $\begin{array}{l}\text { Semen, rangka } \\
\text { kayu, rak } \\
\text { kayu/Cements, } \\
\text { wood frames, } \\
\text { nood shelves }\end{array}$ & $\begin{array}{l}\text { Kayu, kasa besi, } \\
\text { seng/Woods, mesh } \\
\text { uiring, zinc plates }\end{array}$ \\
\hline & $\begin{array}{l}\text { - Jarak sumber asap/ } \\
\text { Distance from smoke source }\end{array}$ & $\pm 40 \mathrm{~cm}$ & $\pm 85 \mathrm{~cm}$ & $\begin{array}{l}\text { Lt. } 1 \pm 55 \\
\mathrm{~cm} / 1 \mathrm{st} \text { floor; } \\
\pm 55 \mathrm{~cm} \\
\text { Lt. } 2 \pm 200 \\
\mathrm{~cm} / 2 \mathrm{nd} \text { floor; } \\
\pm 200 \mathrm{~cm}\end{array}$ & $\pm 5-10 \mathrm{~cm}$ \\
\hline & $\begin{array}{l}\text { - Kelengkapan lain/ } \\
\text { Additional equipment }\end{array}$ & - & $\begin{array}{l}\text { Termometer, } \\
\text { pengatur udara/ } \\
\text { Thermometer, air } \\
\text { valve }\end{array}$ & $\begin{array}{l}\text { Termometer, } \\
\text { pengatur udaral } \\
\text { Thermometer, } \\
\text { door ventilation }\end{array}$ & - \\
\hline d. & $\begin{array}{l}\text { Perebusan sebelum } \\
\text { pengasapan/Boiling before } \\
\text { smoking }\end{array}$ & - & - & $\begin{array}{l}90{ }^{\circ} \mathrm{C} \text { selama } 2 \\
\text { jam } / 90{ }^{\circ} \mathrm{C} \text { for } 2 \\
h\end{array}$ & - \\
\hline e. & Penggaraman/Salting/Brining & - & - & - & - \\
\hline$\overline{f .}$ & $\begin{array}{l}\text { Perendaman dalam bumbu } \\
\text { rempah }\end{array}$ & - & $\begin{array}{l}\text { Dilakukan/ } \\
\text { Performed }\end{array}$ & - & - \\
\hline g. & $\begin{array}{l}\text { Pengeringan sebelum } \\
\text { pengasapan/Drying before } \\
\text { smoking }\end{array}$ & - & $\begin{array}{l}\text { Pada tray I, II, III, } \\
\text { suhu } 60-80^{\circ} \mathrm{C} \text {, } \\
\text { waktu keseluruhan } \\
3 \text { jam } 45 \text { menit/ } \\
\text { On the } 1^{\text {st }}, 2^{\text {nd }} \text {, } \\
3^{\text {rd }} \text { trays, } 60-80 \\
{ }^{\circ} \mathrm{C} \text {, overall time } \\
\text { was } 3 \mathrm{~h} 45 \text { min }\end{array}$ & $\begin{array}{l}\text { Pada oven } \\
\text { terpisah, } 90{ }^{\circ} \mathrm{C} \\
\text { selama } 15 \\
\text { menit/ } \\
\text { On a separate } \\
\text { oven at } 90^{\circ} \mathrm{C} \\
\text { for } 15 \mathrm{~min}\end{array}$ & - \\
\hline
\end{tabular}


Tabel 2. Proses pengasapan 4 jenis ikan asap di Indonesia (lanjutan)

Table 2. Smoking process of four smoked fish in Indonesia (continued)

\begin{tabular}{|c|c|c|c|c|c|}
\hline \multirow{2}{*}{\multicolumn{2}{|c|}{ Parameter/Parameters }} & \multicolumn{4}{|c|}{ Jenis Ikan Asap/Kinds of Smoked Fish } \\
\hline & & Ikan fufu & Ikan salai & Ikan kayu & Ikan pe \\
\hline h. & $\begin{array}{l}\text { Suhu pengasapan/Smoking } \\
\text { temperature }\end{array}$ & $\pm 80^{\circ} \mathrm{C}$ & $60-80^{\circ} \mathrm{C}$ & $\begin{array}{l}12 \text { jam pertama } \\
90{ }^{\circ} \mathrm{C} \text { lalu } \\
\text { diturunkan } \\
\text { menjadi } 40 \\
{ }^{\circ} \mathrm{C} / 90{ }^{\circ} \mathrm{C} \text { in the } \\
\text { first } 12 \text { hours } \\
\text { and then was } \\
\text { decreased to } 40 \\
{ }^{\circ} \mathrm{C}\end{array}$ & $\pm 80^{\circ} \mathrm{C}$ \\
\hline i. & $\begin{array}{l}\text { Waktu pengasapan/Smoking } \\
\text { time }\end{array}$ & $4 \mathrm{jam} / \mathrm{h}$ & $10 \mathrm{menit} / \mathrm{min}$ & $7-30$ hari/d & $30 \mathrm{menit} / \mathrm{min}$ \\
\hline j. & $\begin{array}{l}\text { Pengeringan setelah } \\
\text { pengasapan/Drying after } \\
\text { smoking }\end{array}$ & - & $\begin{array}{l}\text { Pada tray IV dan } \\
\mathrm{V} \text {, suhu } 60^{\circ} \mathrm{C} \text {, } \\
\text { waktu keseluruhan } \\
19 \text { jam/On the } 4 \\
\text { and } 5 \text { th trays, at } \\
60^{\circ} \mathrm{C} \text {, overall time } \\
\text { was } 19 \text { hours }\end{array}$ & - & - \\
\hline $\mathrm{k}$. & $\begin{array}{l}\text { Penanganan lainnya/Other } \\
\text { treatment }\end{array}$ & $\begin{array}{l}\text { Pengolesan } \\
\text { warna } \\
\text { sebelum } \\
\text { diasapi/Food } \\
\text { colorant was } \\
\text { added before } \\
\text { the smoking } \\
\text { process }\end{array}$ & $\begin{array}{l}\text { Penutupan dengan } \\
\text { karung goni } \\
\text { selama } \\
\text { pengeringan pada } \\
\text { tray VIThe } \\
\text { smoked fish was } \\
\text { covered by a } \\
\text { gunny sack during } \\
\text { the final drying } \\
\text { process on 5th } \\
\text { tray }\end{array}$ & $\begin{array}{l}\text { Penganginan } \\
\text { ikan setelah } \\
\text { ikan diasapi 3-7 } \\
\text { hari/Smoked } \\
\text { fish were put in } \\
\text { the open air for } \\
3 \text { to } 7 d\end{array}$ & - \\
\hline
\end{tabular}

pengeringan pendahuluan sebelum proses pengasapan pada pembuatan ikan salai yang menyebabkan permukaannya mengkilap. Lama pengeringan dapat berlangsung mulai dari beberapa menit hingga berjam-jam, tergantung jenis ikan (semakin rendah kandungan lemak ikan pada spesies yang sama maka pengeringan berlangsung lebih cepat), cara preparasinya (semakin rendah kandungan garam maka pengeringan berlangsung lebih cepat) dan tingkat kondisi pengeringan eksternal (suhu udara, kelembaban, kecepatan aliran udara) (Doe, 1998).

Waktu yang diperlukan untuk pengasapan dingin seperti pada pengasapan ikan kayu biasanya lebih lama (dapat berlangsung berhari-hari) dibandingkan dengan pengasapan panas (Rozum, 2009). Sirkulasi udara dan kelembaban akan mempengaruhi waktu pengasapan (Snyder, 1996). Proses penganginan ikan selama beberapa waktu dilakukan dalam pengolahan ikan kayu. Hal ini senada dengan penelitian yang dilakukan oleh Giyatmi et al. (2000) pada pengasapan katsuobushi yang kemudian dibiarkan dalam udara terbuka selama 1 hari dengan tujuan agar kadar air filet seragam.

Ikan pe masih memiliki kandungan air yang tinggi karena biasanya ikan pe diolah kembali menjadi jenis masakan lain. Pengaruh pengasapan dalam hubungannya dengan kualitas dan umur simpan produk tergantung pada persiapan bahan mentah, jenis pengasapan, kelembaban udara, Iaju pengasapan, suhu asap, densitas asap, dan komposisi asap serta waktu pengasapan (Doe, 1998). 
Kualitas yang lebih baik dapat diperoleh ketika produk diberi perlakuan asap dari pembakaran lambat atau bara kayu. Jenis dan campuran kayu yang dipilih untuk pengasapan dan bumbu yang digunakan pada umumnya berdasarkan pengalaman dari masingmasing pengolah (Toth \& Potthast, 1984).

\section{Pengujian Menggunakan Metode Quantitave Descriptive Analysis (QDA ${ }^{\circledR}$ )}

Data hasil QDA ${ }^{\circledR}$ berdasarkan rata-rata penilaian 10 panelis terlatih sebanyak 4 sesi pengujian untuk atribut aroma dan rasa tersaji pada Tabel 3 dan dalam bentuk spider web pada Gambar 1. Hasil QDA ${ }^{\circledR}$ untuk atribut aroma menunjukkan bahwa ikan kayu memiliki intensitas aroma fishy dan woody yang lebih tinggi dari ikan asap jenis lainnya. Ikan pe memiliki intensitas aroma burnt dan smoky yang lebih tinggi serta ikan salai memiliki intensitas aroma fatty dan sweet yang lebih tinggi dibandingkan ikan asap jenis lainnya. Hasil deskripsi atribut rasa menunjukkan bahwa ikan kayu memiliki intensitas rasa gurih yang lebih tinggi daripada ikan lainnya, pada ikan fufu intensitas rasa pahit, asin dan asamnya lebih tinggi serta ikan salai memiliki intensitas rasa manis yang lebih tinggi daripada ketiga jenis ikan asap lainnya.

Menurut Guillen \& Errecalde (2002), amin-amin volatil seperti dimetil dan trimetilamin sering dihubungkan dengan off-flavour dan biasanya terdeteksi sebagai komponen volatil pada ikan segar. Trimetilamin memiliki deskripsi aroma amis (fishy), tajam (pungent) dan seperti amonia (Burdock, 2005), oleh karena itu aroma fishy kemungkinan besar berasal dari komponen trimetilamin yang berada pada bahan baku ikan kayu yaitu ikan cakalang yang termasuk jenis ikan air laut.

Atribut aroma woody yang terdeteksi pada ikan kayu juga pernah terdeteksi pada penelitian flavor asap kayu. Atribut sensoris woody terdeteksi dominan pada salah satu fraksi asap penelitian Kostyra \&
Pikielna (2006) dan dikarakterisasi oleh adanya jumlah senyawa golongan karbonil yang menurun, sedangkan fenol, guaiacol dan syringol jumlahnya meningkat. Ikan kayu juga diketahui memiliki komponen fenolik yang merupakan komponen khas pada produk yang diasapi.

Atribut sensoris aroma burnt digunakan juga oleh Varlet et al. (2007), pada penelitiannya mengenai aroma salmon asap. Aroma burnt dapat ditimbulkan antara lain oleh senyawa atau golongan senyawa seperti 2-butenolide, 2,6-dimethoxy-4-methylphenol, 2,6-dimethoxy-4-ethylphenol, 2,6-dimethoxy-4propylphenol, 2,6-dimethoxy-4-propenylphenol, pyrocatechol, 3-methylpyrocatechol, 4methylpyrocatechol, 4-ethylpyrocatechol, 2acetylfuran, pyrrole (Kim et al., 1974; Toth \& Potthast 1984; Maga, 1987; Varlet et al., 2007). Senyawasenyawa dari golongan fenol memberikan peran yang besar terhadap aroma burnt ini dan kemungkinan terdapat banyak pada ikan pe karena ikan pe diasapi pada jarak yang cukup dekat dengan metode pengasapan panas dan dalam keadaan masih basah karena tidak mengalami proses pengeringan pendahuluan. Fenol pada asap lebih mudah terserap ketika permukaan ikan agak basah. Asap yang lembab akan membentuk lapisan kelembaban pada permukaan produk yang menyebabkan partikel asap menyerap lebih cepat (Berkel, 2004).

Atribut sensoris aroma smoky merupakan atribut sensoris yang khas pada produk asap dan senyawasenyawa dari kelompok fenol merupakan sumber utamanya. Senyawa-senyawa yang memiliki deksripsi smoky antara lain ialah 2-methoxyphenol, 2methylphenol, 4-methylguaiacol, 4-ethylguaiacol, guaiacol, 2,6-dimethoxyphenol (syringol) (Maga 1987). Jumlah kadar fenol akan dipengaruhi oleh proses pengolahan seperti lamanya waktu pengasapan, komposisi asap, jarak sumber asap dari bahan baku, ketebalan asap, jenis kayu dan kondisi pengasapan lainnya (Rusz \& Miller, 1977; Toth \& Potthast, 1984). Ikan pe memiliki intensitas aroma smoky yang lebih

Tabel 3. Hasil QDA atribut aroma dan rasa 4 jenis ikan asap

Table 3. QDA results of taste and aroma attributes of four smoked fish

\begin{tabular}{|c|c|c|c|c|c|c|c|c|c|c|c|}
\hline \multirow{2}{*}{$\begin{array}{c}\text { Jenis Ikan } \\
\text { Asapl } \\
\text { Smoked Fish } \\
\text { Products }\end{array}$} & \multicolumn{6}{|c|}{$\begin{array}{c}\text { Atribut Aromal } \\
\text { Aroma Attributes }\end{array}$} & \multicolumn{5}{|c|}{$\begin{array}{c}\text { Atribut Rasal } \\
\text { Taste Attributes }\end{array}$} \\
\hline & $\begin{array}{l}\text { Amisl } \\
\text { Fishy }\end{array}$ & $\begin{array}{l}\text { Hangusl } \\
\text { Burnt }\end{array}$ & $\begin{array}{l}\text { Manisl } \\
\text { Sweet }\end{array}$ & $\begin{array}{l}\text { Asap/ } \\
\text { Smoky }\end{array}$ & $\begin{array}{l}\text { Lemak } \\
\text { Fatty }\end{array}$ & $\begin{array}{l}\text { Kayul } \\
\text { Woody }\end{array}$ & $\begin{array}{l}\text { Manisl } \\
\text { Sweet }\end{array}$ & $\begin{array}{l}\text { Asinl } \\
\text { Salty }\end{array}$ & $\begin{array}{l}\text { Asaml } \\
\text { Sour }\end{array}$ & $\begin{array}{l}\text { Gurihl } \\
\text { Umami }\end{array}$ & $\begin{array}{l}\text { Pahit/ } \\
\text { Bitter }\end{array}$ \\
\hline Fufu & 46.35 & 27.45 & 25.47 & 46.15 & 25.98 & 328.33 & 28.13 & 34.17 & 39.82 & 27.48 & 28.58 \\
\hline Salai & 35.35 & 31.02 & 28.75 & 55.47 & 27.57 & 25.42 & 33.10 & 27.92 & 25.18 & 44.72 & 18.57 \\
\hline $\mathrm{Pe}$ & 35.83 & 36.02 & 22.62 & 62.32 & 25.28 & 26.13 & 19.03 & 27.95 & 33.00 & 33.68 & 25.65 \\
\hline Кауи & 53.97 & 25.12 & 24.63 & 48.08 & 23.27 & 37.77 & 24.72 & 31.10 & 29.15 & 47.62 & 25.80 \\
\hline
\end{tabular}




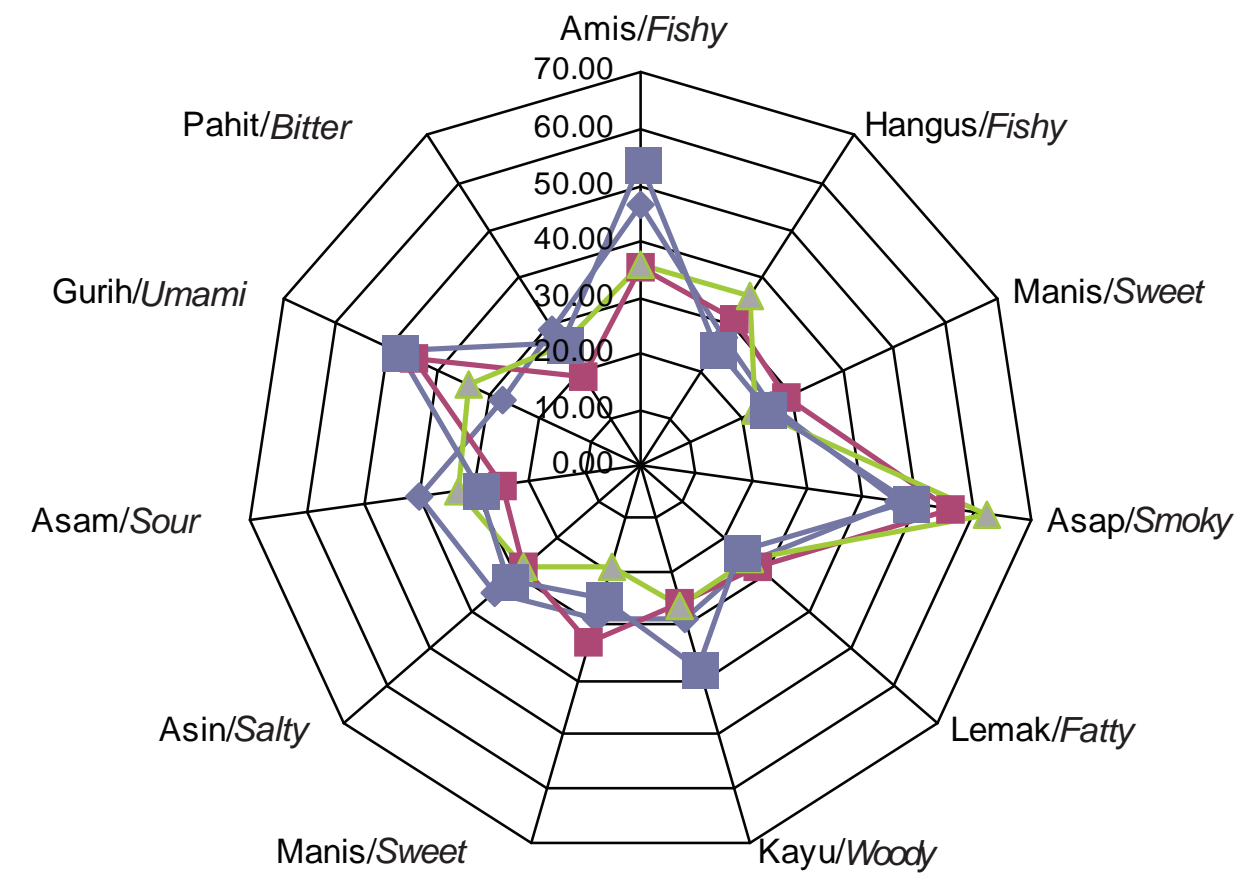

Rasa/Taste

- Ikan Fufu

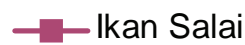

AromalFlavor

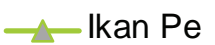

Ikan Kayu

Gambar 1 Profil sensori aroma dan rasa ikan asap fufu, salai, pe dan kayu.

Figure 1. Taste and flavor sensory profiles of fufu, salai, pe and kayu fish.

tinggi dengan alasan yang sama dengan terdeteksinya aroma burnt pada produk ini yaitu karena proses pengasapannya dan kelembaban permukaan bahan bakunya.

Senyawa-senyawa yang dapat memberikan deskripsi fatty atau berlemak di antaranya ialah 3,5octadien-2-one, hexanal, heptanal, oktanal, nonanal, octanoic acid, decanoic acid (Cha et al., 1992; Guillen \& Errecalde, 2002; Varlet et al., 2007; Jonsdottir et al., 2008). Kandungan lemak lebih dipengaruhi oleh metode pengolahan yang dilakukan dibandingkan karakteristik awal bahan bakunya (Birkeland et al., 2007). Berkel (2004) menyatakan bahwa pengasapan panas menghasilkan produk dengan kandungan lemak yang rendah karena lemak akan meleleh keluar. Ikan salai diasapi dengan metode pengasapan dingin.

Senyawa atau golongan senyawa yang menghasilkan deskripsi aroma sweet dari asap kayu di antaranya ialah furfuraldehida, alkyl phenyl ketone, furfural, 5-methylfurfural, 2-(5-Methylfuryl)methylketone, 2-ethylfuran, 2-furanmethanol, decanal, dimethylphenol, 4-methylguaiacol, guaiacol, o-cresol, 2-ethyl-1-hexanol, dimethyl sulfide, diethyl sulfide; ethyl acetate dan ethyl decanoate (Yajima et al., 1983; Maga 1987; Guillen \& Errecalde, 2002; Linder \& Ackman 2002). Penambahan berbagai jenis bumbu pada pembuatan ikan salai akan mempengaruhi komposisi flavornya. Minyak volatil dari rempahrempah mewakili aspek aromatik dan berkontribusi besar pada flavornya. Minyak nonvolatil (oleoresin) merupakan komponen flavor seperti rempah-rempah yang memberikan kesan tajam menusuk, panas, manis atau pahit (Brown, 2009).

Atribut sensori berikutnya yang diamati adalah rasa. Senyawa aktif pembentuk rasa (taste-active components) pada umumnya ialah senyawa nonvolatil, seperti asam amino bebas, nukleotida, gula, garamgaram mineral, basa organik, asam organik, dan senyawa inorganik. Senyawa aktif pembentuk rasa ini sangat berperan secara signifikan pada perubahan rasa produk hasil perikanan jika dihilangkan dari suatu campuran (atau ditambahkan). Taste-active components seperti glutamat, inosin monofosfat dan glisin berpengaruh terhadap rasa gurih dan tingkat kemanisan produk hasil perikanan (Kawai et al., 2009). Rasa dipengaruhi oleh beberapa 
faktor yaitu senyawa kimia, suhu, konsentrasi dan interaksi dengan komponen rasa yang lain. Rasa asam disebabkan oleh donor proton, misalnya asam cuka. Intensitas rasa asam tergantung pada ion $\mathrm{H}+$ yang dihasilkan dari hidrolisis asam (Winarno, 2008). Pada ikan asap fufu, rasa asam ini kemungkinan ditimbulkan dari adanya asam-asam organik yang terkandung di dalam asap, atau hasil reaksi penguraian pada komponen-komponen ikan asap yang dapat menghasilkan asam. Asam merupakan hasil dekomposisi penting dari selusosa dan hemiselulosa (Rozum, 2009), yang terkandung dalam bahan bakar sebagai sumber asap.

Rasa asin dihasilkan oleh sebagian garam-garam anorganik. Garam anorganik yang umum adalah $\mathrm{NaCl}$ (Winarno, 2008). Demikian juga dengan proses hidrolisis protein yang dapat menghasilkan asam amino taste-active dan peptida yang berperan pada karakteristik rasa produk seperti ikan asin dan cumi kering (Doe, 1998). Ion natrium bertanggung jawab bagi flavor yang berasal dari garam. Fungsi yang penting bagi persepsi flavor bukan saja rasa asin yang diberikan natrium tapi juga peningkatan intensitas dari flavor lain yang dihasilkan dengan adanya natrium (Sebranek, 2009). Pada sampel ikan asap yang diuji adanya rasa asin lebih dipengaruhi oleh kandungan alami senyawa kimia ikan asap dan interaksi yang terjadi selama pengasapan daripada proses pengolahannya karena tidak dilakukannya proses penggaraman pada seluruh prosedur pengolahan ikan asap (Tabel 2).

Rasa manis ditimbulkan oleh senyawa organik alifatik yang mengandung gugus $\mathrm{OH}$ seperti alkohol, beberapa asam amino, aldehida, dan gliserol. Sumber rasa manis yang utama adalah gula atau sukrosa, monosakarida dan disakarida lainnya (Winarno, 2008). Pada ikan biasanya terdapat gula bebas yang terkandung yaitu glukosa dan ribosa (Okada, 1990). Kemungkinan adanya asam amino dan gula yang berada pada ikan salai mempengaruhi atribut sensoris manis yang terdeteksi oleh panelis pada ikan ini. Adanya beberapa asam amino yang memiliki rasa manis seperti glisin dan alanin juga turut mempengaruhi atribut rasa manis (Okada, 1990). Rasa manis juga dapat dipengaruhi oleh beberapa senyawa golongan fenol yang berasal dari asap dan menempel pada daging ikan salai. Senyawa-senyawa seperti dimetilfenol, 4-metilguiakol, guaiakol, dan orto kresol diketahui menimbulkan rasa manis khas pada produk asap (Maga, 1987).

Rasa pahit pada ikan fufu dapat disebabkan oleh alkaloid-alkaloid seperti kafein, kuinon, glikosida, amonium, senyawa fenol, Mg, dan Ca (Winarno, 2008). Fenol, cresol (metilfenol), guaiacol, methyl- dan ethyl guaiacol memiliki citarasa panas (hot) dan pahit (Maga, 1987). Senyawa yang dapat memberikan rasa pahit lainnya di antaranya ialah asam amino arginin, metionin, dan valin (Yamaguchi \& Watanabe, 1990).

Rasa gurih dihubungkan dengan adanya senyawa seperti asam glutamat atau garamnya pada bahan makanan, misalnya monosodium glutamat dan jenis 5-nukleotida seperti Inosin 5-monofosfat (IMP), guanidin 5-monofosfat (GMP) (Winarno, 2008). Asam glutamat bebas terkandung pada seluruh spesies ikan dan merupakan kontributor rasa paling penting dan umami dari katsuobushi (ikan kayu yang difermentasi) terutama disebabkan oleh IMP (Yamaguchi \& Watanabe, 1990).

Metode pengasapan yang dilakukan akan berpengaruh pada komponen yang terbentuk dalam ikan asap. Komponen-komponen ini kemungkinan berasal dari hasil pirolisis komponen kayu yang menempel dan berpenetrasi pada daging ikan, komponen alami yang terkandung dalam ikan itu sendiri dan hasil interaksi antara keduanya. Menurut Guillen et al. (2006), komponen asap akan diserap oleh permukaan ikan dan selanjutnya dapat bereaksi atau berinteraksi dengan komponen ikan selama proses pengasapan. Hal yang sama dinyatakan oleh Rusz \& Miller (1977) bahwa proses penyerapan asap akan disertai proses kimia, yaitu interaksi antara senyawa asap dengan unsur-unsur pokok penyusun makanan. Komposisi asap dan sifat flavornya dapat dipengaruhi oleh berbagai perlakuan pengasapan (Toth \& Potthast 1984). Adanya senyawa-senyawa kimia dari golongan fungsional tertentu yang berasal dari asap, ikan maupun hasil interaksinya juga akan mempengaruhi intensitas flavor yang diterima.

\section{Pengolahan Data Menggunakan Principle Component Analysis (PCA)}

Nilai hasil PCA dapat menunjukkan titik lokasi masing-masing sampel ikan asap di sekitar atribut sensoris aroma (fishy, sweet, burnt, woody, fatty, smoky) dan rasa (manis, asam, pahit, asin, gurih) yang menjadi karakteristik sampel tersebut dalam suatu grafik. Dua komponen utama (PC1, PC2) digunakan untuk menerjemahkan data-data karena keduanya telah dapat menjelaskan $84 \%$ dari total keragaman yang ada pada data atribut sensoris (PC1 47\%; PC2 37\%). Menurut Setyaningsih et al. (2010), komponen utama berikutnya akan diambil jika komponen utama tersebut belum mampu menjelaskan $70 \%$ dari total keragaman.

Gambar 2 menunjukkan grafik Bi-plot yang menjelaskan hubungan antara sampel ikan asap dan atribut sensoris aroma serta rasa (variabel) secara keseluruhan. Grafik ini memberikan informasi 


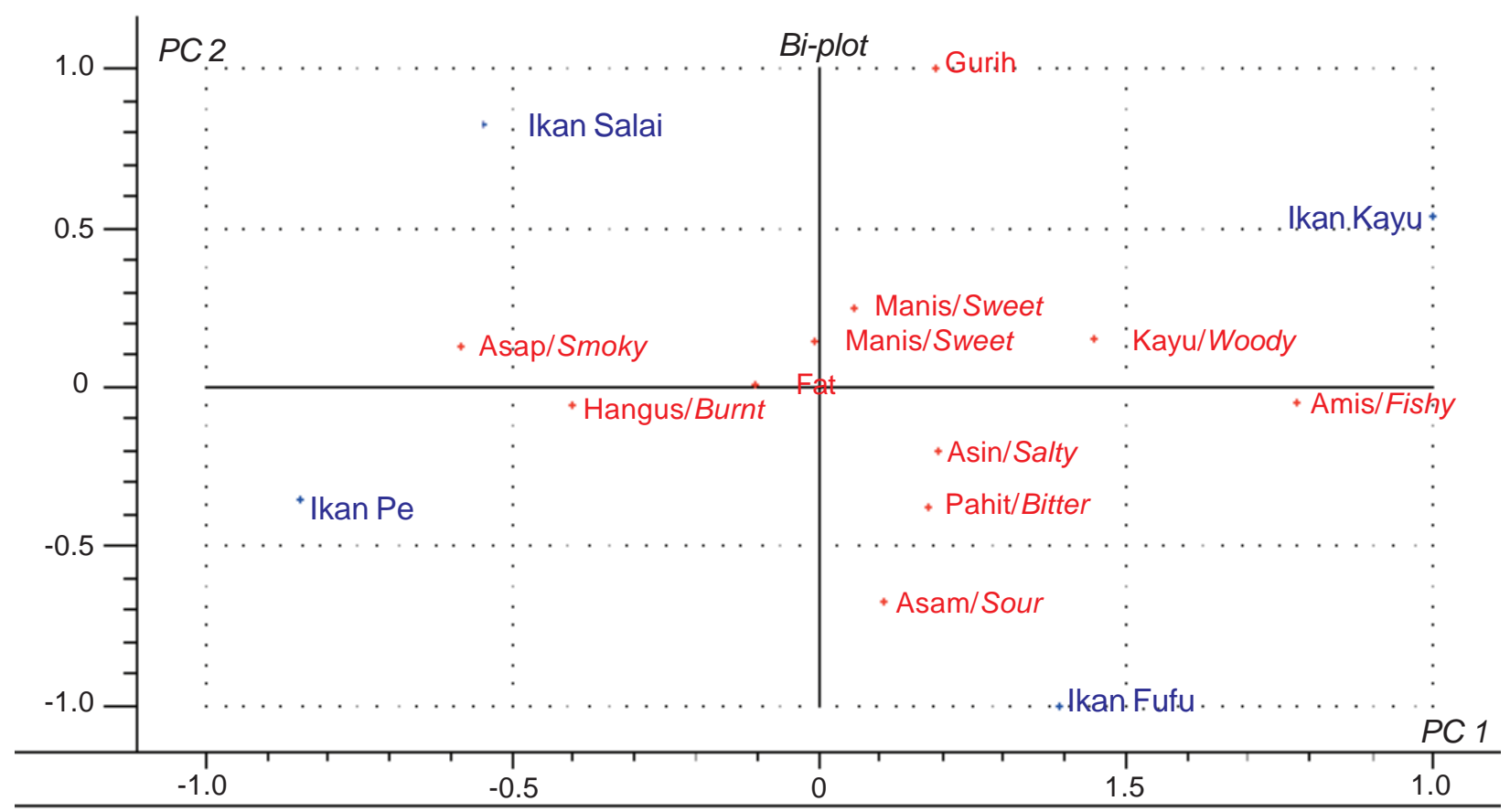

qdasf, X-expl: 47\%, 37\%

Gambar 2 Diagram Bi-plot PCA atribut sensori dan sampel ikan asap.

Figure 2. PCA Bi-plot of taste and aroma sensory attributes and smoked fish samples.

mengenai hubungan antar variabel, kemiripan relatif antar objek pengamatan, dan posisi relatif antar objek pengamatan dengan variabel. Jarak antara variabel maupun sampel menunjukkan hubungan di antara variabel maupun sampel tersebut. Hubungan antara dua titik sampel dapat dilihat dengan membandingkan jaraknya dengan titik-titik dari variabel (Setyaningsih et al., 2010).

Ikan kayu terdapat pada kuadran pertama, dan dikarakterisasi oleh atribut aroma woody, rasa manis dan gurih. Hasil QDA ${ }^{\circledast}$ aroma woody dan rasa gurih ikan kayu memberikan deskripsi hasil yang sama dengan hasil grafik PCA. Rasa manis yang menjadi karakteristik ikan kayu dipengaruhi oleh kandungan karbohidrat dan kandungan asam amino bebas yang memiliki rasa manis seperti glisin, serin, alanin, prolin, dan treonin (Winarno, 2008; Liu et al., 2009). Atribut aroma woody dan rasa manis pada ikan kayu terletak pada kuadran yang sama. Menurut Maga (1987), beberapa senyawa guaiakol dapat menimbulkan deskripsi odor woody (4-allylguaiacol) dan citarasa yang manis (4-methylguaiacol).

Sampel ikan fufu berada di kuadran kedua dan dikarakterisasi oleh atribut rasa asin, pahit, asam dan fishy. Hasil pengujian QDA ${ }^{\circledR}$ memberikan deskripsi hasil rasa yang sama yaitu ikan fufu memiliki intensitas rasa asin, pahit dan asam yang tinggi. Karakteristik fishy yang terletak dalam kuadran berdekatan dengan ikan kayu ini dapat dijelaskan karena kedua ikan asap ini memiliki bahan baku yang sama yaitu ikan cakalang yang merupakan ikan air laut yang mengandung trimetilamin.

Ikan pe pada kuadran ketiga dikarakterisasikan dari aroma burnt yang berada pada kuadran yang sama dan hasilnya juga sama dengan hasil pengujian $\mathrm{QDA}^{\circledast}$. Atribut burnt memiliki korelasi negatif dengan atribut yang berada pada kuadran pertama dan kedua. Sampel ikan salai pada kuadran keempat dikarakterisasi dari atribut aroma fat (fatty), sweet dan smoky. Hasil QDA ${ }^{\circledast}$ memberikan deskripsi yang sama untuk aroma fatty dan sweet di mana ikan salai memiliki intensitas yang tinggi untuk kedua aroma ini. Aroma fatty terdapat pada perbatasan sumbu kuadran ke tiga dan ke empat tetapi sedikit lebih memasuki kuadran ke empat dan mendekati titik pusat kemungkinan karena intensitas aroma fatty yang dirasakan oleh panelis tidak terlalu terpaut jauh (ikan salai 27,57; ikan fufu 25,98; ikan pe 25,28; ikan kayu 23,27). Ikan pe memiliki nilai intensitas smoky yang tinggi menurut hasil pengujian $\mathrm{QDA}^{\circledR}$ dan pada posisi berikutnya ialah ikan salai $(62,32$ dan 55,47$)$. Ikan pe memiliki intensitas smoky tinggi karena produk ini diproses pada jarak pengasapan paling dekat dan kandungan airnya yang masih tinggi akan mempermudah proses penempelan komponenkomponen dari asap. Komponen fenol merupakan kontributor utama pada aroma asap (Maga, 1987). 
Ikan salai juga memiliki karakteristik smoky karena dipengaruhi oleh proses pengolahan yang cukup lama (1 hari) dan daging ikan lele yang digunakan tidak terlalu tebal dibandingkan bahan baku ikan asap lainnya sehingga partikel asap dapat lebih meresap ke dalam bagian tertentu pada permukaan ikan salai dan mudah dideteksi oleh panelis. Atribut aroma smoky dan burnt memiliki hubungan (korelasi) yang dekat tetapi dalam kuadran yang berbeda sehingga dapat disimpulkan bahwa atribut aroma smoky dan burnt memiliki hubungan kesan yang berdekatan tetapi masih dapat dibedakan karakteristiknya dengan mudah.

Hasil PCA (PC1 47\%; PC2 37\%) menunjukkan bahwa masing-masing sampel ikan asap dikelompokkan ke dalam kuadran yang berbeda. Hal ini menunjukkan bahwa keempat sampel ikan asap memiliki deskripsi dan karakteristik dominan yang berbeda satu sama lain sehingga dapat disimpulkan lebih lanjut bahwa perbedaan-perbedaan yang ada pada masing-masing sampel ikan asap tersebut dapat dikenali melalui pengujian sensoris dengan baik. Ikan asap yang diuji memiliki kekhasan masing-masing, baik dalam tahap preparasi, proses, kondisi pengasapan maupun bahan baku dan hal ini mempengaruhi keragaman karakteristik yang dominan pada masing-masing produk.

\section{KESIMPULAN}

Hasil analisis QDA menunjukkan bahwa ikan kayu memiliki intensitas aroma fishy $(53,97)$, woody $(37,77)$, dan rasa gurih $(47,62)$ yang lebih dominan; ikan pe memiliki intensitas aroma burnt $(36,02)$ dan smoky $(62,32)$ yang lebih dominan; ikan fufu memiliki intensitas rasa pahit $(28,58)$, asin $(34,17)$ dan asam $(39,82)$ yang lebih dominan serta ikan salai memiliki intensitas aroma fatty $(27,57)$, sweet $(28,75)$, dan rasa manis $(33,10)$ yang lebih dominan dibandingkan ikan asap jenis lainnya.

Hasil PCA (PC1 47\%; PC2 37\%) yang dilakukan lebih jauh lagi menunjukkan kedekatan hubungan atau korelasi antara masing-masing atribut dan sampel ikan asap yang diuji. Ikan kayu terdapat pada kuadran pertama dan dikarakterisasi oleh atribut aroma woody, rasa manis dan gurih. Sampel ikan fufu berada di kuadran kedua dan dikarakterisasi oleh atribut rasa asin, pahit, asam dan fishy. Ikan pe pada kuadran ketiga dikarakterisasi oleh aroma burnt yang berada pada kuadran yang sama. Sampel ikan salai pada kuadran keempat dikarakterisasi dari atribut aroma fat (fatty), sweet, dan smoky.

Hasil evaluasi sensoris deskriptif menunjukkan bahwa karakteristik organoleptik masing-masing ikan asap dapat dibedakan dengan baik berdasarkan atribut aroma dan rasa yang menjadi karakteristik khasnya. Adanya senyawa-senyawa kimia dari golongan fungsional tertentu yang berasal dari asap, ikan maupun hasil interaksinya juga akan mempengaruhi intensitas flavor yang diterima. Ikan asap yang diuji memiliki kekhasan masing-masing, baik dalam tahap preparasi, proses, kondisi pengasapan maupun bahan baku dan hal ini mempengaruhi keragaman karakteristik yang dominan pada masing-masing produk.

\section{DAFTAR PUSTAKA}

Aqliyanto, N. 2005. Pengaruh Suhu dan Lama Pengasapan terhadap Mutu Ikan Lele Dumbo Asap. Skripsi. Fakultas Perikanan dan Kelautan, Institut Pertanian Bogor, Bogor.

Berkel, B.M. van, Boogard, B. van de, and Heijnen, C. 2004. Preservation of Fish and Meat. Agromisa Foundation, Wageningen. $86 \mathrm{pp}$.

Birkeland, S., Rora, A.M.B., Skara, T., and Bjerkeng, B. 2004. Effects of cold smoking procedures and raw material characteristics on product yield and quality parameters of cold smoked Atlantic salmon (Salmo salar L.) fillets. Food Research International. 37: 273286

Brown, J.J. 2009. Spices, seasonings and flavors. In Tarte, R. (ed.). Ingredients in Meat Products. Springer Science, New York. p. 199-210.

Burdock, A.G. 2005. Fenaroli's Handbook of Flavor Ingredients Fifth Edition. CRC Press, Boca Raton. 2009 pp.

Cha, Y.J., Baek, H.H., and Hsieh, C.Y. 1992. Volatile components in flavour concentrates from crayfish processing waste. J. Sci. Food. Agric. 58: 239-248

Codex Alimentarius. 1979. Volume 9: recommended international code of practice for smoked fish CAC/ RCP 25-1979. www.codexalimentarius.net/download/ standards/123/CXP_025e.pdf. Diakses pada tanggal 15 Maret $201 \overline{0}$

Doe, P.E. 1998. Fish Drying and Smoking: Production and Quality. Technomic Publication, Pennsylvania. $245 \mathrm{pp}$.

Giyatmi, Basmal, J., Wijaya C.H., dan Fardiaz, S. 2000. Pengaruh jenis kapang dan lama fermentasi terhadap mutu ikan kayu (katsuobushi) cakalang. Buletin Teknologi dan Industri Pangan. 9: 10-20.

Guillen, M. and Errecalde, M. 2002. Volatile components of raw and smoked black bream (Brama raii) and rainbow trout (Onchorhynchus mykiss) studied by means of solid phase microextraction and gas chromatography/mass spectrometry. J. Sci. Food Agric. 82: 945-952.

Guillen, M.D., Errecalde, M.C., Salmeron, J., and Casas, C. 2006. Headspace volatile components of smoked Swordfish (Xiphias gladius) and Cod (Gadus morhua) detected by means of solid phase microextraction and gas chromatography-mass spectrometry. Food Chem. 94: 151-156. 
Jonsdottir, R., Olafsdottir, G., Chanie, E., and Haugen, J. 2008. Volatile compounds suitable for rapid detection as quality indicators of cold smoked salmon (Salmo salar). Food Chem. 109: 184-195.

Kawai, M., Uneyama, H., and Miyano, H. 2009. Taste active components in food with concentration on umami compounds. Journal of Health Science. 55(5): 667673.

Kim, K., Kirata, T., and Fujimaki, M. 1974. Identification of flavor constituents in carbonyl, non-carbonyl neutral and basic fractions of aqueous smoke condensates. Agr. Biol. Chem. 38: 53-63.

Kostyra, E. and Pikielna, N.B. 2006. Volatiles composition and flavour profile identity of smoke flavourings. Food Quality and Pref. 17: 85-95.

Linder, M. and Ackman, R.G. 2002. Volatile compounds recovered by solid-phase microextraction from fresh adductor muscle and total lipids of sea scallop (Placopecten magellanicus) from Georges Bank (Nova Scotia). J. Food Sci. 67(6): 2032-2037.

Liu, J.K., Zhao, S.M., and Xiong, S.B. 2009. Influence of recooking on volatile and non-volatile compounds found in silver carp Hypophthalmichthys molitrix. Fish Sci. 75: 1067-1075.

Maga, J.A. 1987. The Flavor Chemistry of Wood Smoke. Food Rev. Inter. 3:139-183.

Martinez, O., Salmerón, J., Guillén, M.D., and Casas, C. 2007. Sensorial and physicochemical characteristics of salmon (Salmo salar) treated by different smoking processes during storage. Food Sci. Tech. Inter. 13: 477-484

Meilgaard, M., Civille, G.V., and Carr, B.T. 1999. Sensory Evaluation Techniques 3rd Edition. CRC Press, Boca Raton. $387 \mathrm{pp}$.

Nishibori, K. 1965. Studies on flavor of katsuobushi-II. relation between flavors of "smoke" and of "katsuobushi". Bulletin of the Japanese Society of Scientific Fisheries. 31: 47-50.

Noble, A.C. 2006. Sensory analysis of food flavor. In Voilley, A., and Etievant, P. (eds.). Flavour in Food. Woodhead Publishing Limited, Boca Raton. p. 62-80

Okada, M. 1990. Fish as raw material of fishery products. In Motohiro, T., Kadota, H., Hashimoto, K., Kayama, M., and Tokunaga, T. (eds). Science of Processing Marine Products $\mathrm{Vol}$ I. Japan International Cooperation Agency, Hyogo. p. 1-15.

Oyelese, O.A. 2006. Quality assessment of cold smoked hot smoked and oven dried Tilapia nilotica under cold storage temperature conditions. Journal of Fisheries International. 1: 92-97.

Rieuwpassa, F. 1991. Pengaruh Lama Pengasapan, Kondisi Pengemasan dan Suhu Penyimpanan terhadap Daya Awet Ikan Tongkol (Euthynnus affinis) Asap. Tesis. Institut Pertanian Bogor, Bogor.

Rozum, J. 2009. Smoke flavor. In Tarte, R. (ed.). Ingredients in Meat Product. Properties, Functionality and Applications. Springer Science, New York. p. 211-226.

Rusz, J. and Miller, K.B.M. 1977. Physical and chemical processes involved in the production and application of smoke. Pure and Applied Chemistry. 49: 16391654

Sakakibara, H., Hosokawa, M., and Yajima, I. 1990. Flavor constituents of dried bonito (katsuobushi). Food Reviews International. 6: 553-572.

Sakakibara, H., Ide, J., Yanai, T., Yajima, I.,and Hayashi, K. $1990^{\mathrm{b}}$. Volatile flavor compounds of some kinds of dried and smoked fish. Agric Biol Chem. 54: 9-16.

Sebranek, J. 2009. Basic curing ingredients. In Tarte, R. (ed.). Ingredients in Meat Product. Properties, Functionality and Applications. Springer Science, New York. p. 1-24.

Setyaningsih, D., Apriyantono, A., dan Sari, M.P. 2010. Analisis Sensori Untuk Industri Pangan dan Agro. IPB Press, Bogor. 180 pp.

Snyder, F. 1996. FS-032: Fish smoked at home. www.ohioseagrant.osu.edu/_.../FS/FS032\%20Fish\%20smoked\%20at\%20home.pdf. Diakses pada tanggal10 Maret 2010.

Stone, H., and Sidel, J.L. 2004. Sensory Evaluation and Practices 3rd Edition. Elsevier Academic Press, San Diego. 377 pp.

Toth, L. and Potthast, K. 1984. Chemical aspects of the smoking of meat and meat products. In Chichester, C.O. (ed.). Advances in Food Research. Academic Press Inc., New York. p. 87-158.

Varlet, V., Serot, T., Cardinal, M., Courcoux, P., Cornet, J., Knockaert, C., and Prost, C. 2007. Relationships between odorant characteristics and the most odorant volatile compounds of salmon smoked by four industrial smoking techniques. EUROFOODCHEM XIV, Congress 29-31 August, Paris www.ifremer.fr/docelec/doc/2007/acte-3982.pdf. Diakses pada tanggal 4 Maret 2010.

Winarno, F.G. 2008. Kimia Pangan dan Gizi. M-Brio Press, Bogor. 286 pp.

Yajima, I., Nakamura, M., and Sakakibara, H. 1983. Volatile flavor components of dried bonito (katsuobushi) II. from neutral fraction. Agriculture Biology and Chemistry. 47: 1755-1760.

Yamaguchi, K. and Watanabe, K. 1990. Taste-active components of fish and shellfish. In Motohiro, T., Kadota, H., Hashimoto, K., Kayama, M., and Tokunaga, T. (eds.). Science of Processing Marine Products $\mathrm{Vol}$ I. Japan International Cooperation Agency, Hyogo. p. 111-122.

Zakaria, I.J. 1996. Mempelajari Mutu Ikan Bilih (Mystacoleucus padangensis Bilker) Asap Tradisional serta pengaruh Bumbu dan Lama Pengasapan terhadap Perbaikan Mutu. Tesis. Program Pascasarjana, IPB, Bogor. 